\title{
A widespread necrotizing disease affecting Palythoa caribaeorum (Duchassaing and Michelotti, 1860) on coastal reefs in northeastern Brazil
}

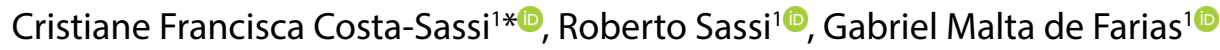

\author{
${ }^{1}$ Universidade Federal da Paraíba, Departamento de Sistemática e Ecologia - Laboratório de Ambientes Recifais e Biotecnologia com \\ Microalgas - Campus I - sn - Cid. Universitária - 58051-090 - João Pessoa - PB - Brazil \\ *Corresponding author: cfcosta_ccosta@yahoo.com
}

\begin{abstract}
A highly aggressive necrotizing disease affecting the zooantharian Palythoa caribaeorum was studied on coastal reefs in northeastern Brazil during March and April of 2008. Approximately $87 \%$ of the colonies at each locality showed wounds ranging from $27 \mathrm{~cm}$ to $1200 \mathrm{~cm}$ long and from 12 to $320 \mathrm{~cm}$ wide. This disease initiates with the darkening of the polyps, followed by the appearance of a rapidly enlarging wound that decomposes colony tissues and eventually exposes the substrate. The exposed areas are subsequently colonized by macroalgae, Zoanthus sociatus, and other benthic organisms. The necrotized areas were dark-colored and expelled fetid odors. Although extremely aggressive, complete mortality of the colonies was not observed. Surviving fragments recomposed the colonies within 6 to 9 months. Recurrences of the disease were in the summer of 2008 and from February/2013 to March/2014. During the study period, we found various colonies having black-spots (early stage of necrotizing disease), suggesting stress conditions. Zooxanthellae densities in those black-spots were always lower than in apparently healthy colonies, with reductions of up to $74 \%$. More than one environmental variable seems to influence the zooxanthellae densities significantly, but there is no evidence of any association with abnormally high water temperature, as thermal variations in the study area were within their normal range. Histological analysis showed losses of tissue organization in colonies with black-spots and necrotizing components with hypertrophy and cell apoptosis of the gastrodermal cells; apoptosis of zooxanthellae and damage in completes mesenteries. All these features showed an inflammatory response to necrosis disease.
\end{abstract}

Descriptors: Zoantharians, Coral disease, Histopathological analysis.

\section{INTRODUCTION}

Zoantharians are abundant in reef environments and along rocky coasts being a principal constituent of the rocky intertidal macrobenthos in places without extensive coral growth (Khushali and Pradeep, 2013). They are rigorous competitors for vital resources and space and exhibit aggressive physical and/or

Submitted on: 9/March/2020

Approved on: 3/July/2020

Editor: Rubens M. Lopes

(c) 2020 The authors. This is an open access article distributed under the terms of the Creative Commons license. chemical interactions with other sessile organisms, including growing over them (Rabelo et al., 2013).

Zoantharians occur on oceanic islands and in different marine environments along the coast of Brazil, having broad geographic distributions from Maranhão State south to Santa Catarina State (Rohlfs and Belém, 1994; Amaral et al., 2000; Santos et al., 2016). They have been examined using various approaches in Brazil, including studies of their reproduction, taxonomy, geographic distributions (Rohlfs and Belém, 1994; Amaral et al., 2000; Boscolo and Silveira, 2005; Soares et al., 2011), anatomy (Rohlfs and Belém, 1994), ecology (Peréz et al., 2005; Santos et al. 2016), pharmacological applications 
(Soares et al., 2006), their predation by marine turtles (Spier and Gerum, 2017), aspects of their mutualistic ecological relationships with zooxanthellae (Soares et al., 2006; Costa et al. 2013; Santos et al., 2016; Spier and Gerum, 2017) and their association with vibrio (Chimetto et al., 2009). Cases of bleaching have been reported in the Palythoa caribaeorum (Migotto, 1997) and Zoanthus sociatus (Soares and Rabelo, 2014).

The history of studies on diseases in benthic marine organisms dates back to approximately 1970 . Furthermore, although today there are more than 35 different types of diseases that affect cnidarians in about 70 countries (Palmer et al., 2012; RodríguezVillalobos and Reyes-Bonilla, 2019), most diseases were described to corals, and almost nothing was recorded for zoantharians.

The few studies on zoantharian diseases are reported by Williams et al. (2011) and Acosta (2001). Williams et al. (2011) described that the zoantharians Palythoa tuberculosa from Palmyra Atoll, Central Pacific, exhibited growth abnormalities, tissue loss, or discoloration due to necrosis. Moreover, Acosta (2001) described and quantified a new disease (unknown pathogen) that affects the Palythoa caribaeorum of the Southwest Atlantic reefs, and this was the first report of mortality related to the disease in zoantharians.

Most diseases and their etiological agents remain uncertain due to difficulties encountered in identifying the pathogens involved (Palmer et al., 2011; Rodríguez-Villalobos and Reyes-Bonilla, 2019). Recent studies have indicated that many diseases are associated with at least one community complex of microorganisms that involve many phyla, such as bacteria, fungi, and cyanobacteria. As the communities of microorganisms observed in healthy tissues are mostly the same as those present in diseased tissues, additional techniques are necessary to understand better the appearance of diseases among cnidarians (Moreira et al., 2014). Researchers have perceived that studies integrating diverse approaches, such as microbiological, cytological, and histological analysis, have been increasingly emphasized.

Work et al. (2016) demonstrated that multiple etiological agents provoked gross lesions observed in several coral species, so the best way of approaching those diseases would be to incorporate histopathological techniques that allow the visualization of the tissue damage provoked. Although histopathological techniques have been employed in different parts of the world to examine disease in corals, no studies have yet been undertaken in Brazil that describes the coral and zoantharian diseases through histological analysis.

For the first time, we report an episode of a massive and highly aggressive necrotizing disease affecting the zoantharian P. caribaeorum on coastal reefs in northeastern Brazil and provide monitoring data of those events and describe through histological analysis the consequences of this disease. Previously, this disease had only been recorded along the northern coast of Sao Paulo State in southeastern Brazil (Acosta, 2001), but no histological analysis has been undertaken to understand better the damage caused to these zoantharians.

\section{MATERIAL AND METHODS}

\section{STUDY AREA}

The monitoring of the disease affecting $P$. caribaeorum was carried out in two periods: the first was carried in March and April of 2008 that determined the latitudinal extent of the disease, and the second was carried out monthly from September 2008 to May 2009, and from February 2013 to March 2014 on the reefs of Cabo Branco, Paraíba State.

The determination of the latitudinal extension of the disease affecting $P$. caribaeorum was undertaken in the States of Rio Grande do Norte (RN) (Búzios reef: $6^{\circ} 00^{\prime} 14^{\prime \prime} \mathrm{S} ; 35^{\circ} 06^{\prime} 19^{\prime \prime} \mathrm{W}$ ), Paraíba (PB) (Picãozinho reef: $7^{\circ} 07^{\prime} 30^{\prime \prime} \mathrm{S}$; $34^{\circ} 48^{\prime} 28^{\prime \prime} \mathrm{W}$; Cabo Branco reef: $7^{\circ} 08^{\prime} 44^{\prime \prime} \mathrm{S} ; 34^{\circ} 47^{\prime} 43^{\prime \prime} \mathrm{W}$ and Carapibus reef: $7^{\circ} 18^{\prime} 03^{\prime \prime} \mathrm{S}$; $34^{\circ} 47^{\prime} 52^{\prime \prime} \mathrm{W}$ ), and Pernambuco (PE) (Porto de Galinhas reef: $8^{\circ} 30^{\prime} 15^{\prime \prime}$; $\left.34^{\circ} 59^{\prime} 54^{\prime \prime} \mathrm{W}\right)$. These reefs are distributed discontinuously for approximately $280 \mathrm{~km}$ along the Atlantic coast of Brazil. These reefs were selected because we observed some colonies of $P$. caribaeorum with discoloration and tissue degradation in a quick inspection dive.

In all study areas, a total of 50 randomly selected colonies in each reef were examined, documented, and photographed using a Canon G9 underwater camera at 12MP. The color patterns of $P$. caribaeorum colonies, the appearance of bleached areas, and/ or black-spots (characteristic of the initial stages of 
the necrotizing disease, according to Acosta, 2001) and degraded lesions (i.e., open wounds) were also examined. The numbers, frequencies, and positions of black-spots and degraded lesions were recorded, and their sizes measured. The area covered by each colony (in $\mathrm{m}^{2}$ ) was calculated by multiplying their maximum length by their maximum width. Since zoantharians are abundant in the reef plateaus, inspections were carried out only in that portion of the reefs. During the latitudinal extent inspection of the disease, sea surface temperatures (reversing thermometer \pm $0.1^{\circ} \mathrm{C}$ ) and salinity (portable refractometer) were measured at all survey sites.

On the second period of the field inspection on the reef at Cabo Branco, sea surface temperatures (reversing thermometer $\pm 0.1{ }^{\circ} \mathrm{C}$ ), salinity (portable refractometer), suspended material (gravimetric analysis), percentages of dissolved oxygen (Winkler method), and monthly rainfall data [(from the nearby city of João Pessoa; using AESA-PB data (http://www. aesa.pb.gov.br)] were collected to complement biological monitoring data. Monthly information on sea surface thermal anomalies and hot spot indications for coral bleaching in the study region were also collected from maps produced by the ORA/ OSDPD/NOAA team available at https://www.ospo. noaa.gov/Products/ocean/sst/anomaly/index.html.

\section{SAMPLE COLLECTIONS}

Monthly collections (from September 2008 to May 2009, and from February to December 2013) were made on the reefs at Cabo Branco by removing four circular fragments $\left(\varnothing 4.52 \mathrm{~cm}^{2}\right)$ of apparently healthy colonies as well as of colonies with black-spots from $P$. caribaeorum to analyze their zooxanthellae. This area allowed removing approximately $10-20$ polyps from $P$. caribaeorum. The fragments were carefully removed using spatulas and tweezers, transferred to individual plastic sacks, and transported to the Laboratory of Reef Environments and the Biotechnology of Microalgae at UFPB (LARBIM/ UFPB). Apparently healthy and black-spot fragments ( $n=4$ for each condition) were removed from the substrate with a spatula and fixed for 12 hours in a $4 \%$ formalin solution (prepared with filtered seawater) and transported to the Laboratory of Reef Environments and the Biotechnology of Microalgae at UFPB (LARBIM/UFPB) for histological analysis.

\section{LABORATORY ANALYSIS}

ANALYSIS OF ZOOXANTHELLAE

The volume of the fragments collected was determined by the volume displacement technique, using a graduated beaker containing $60 \mathrm{ml}$ of filtered seawater. The fragments were placed individually into the graduated beaker; the displaced volume was noted and considered as the volume of the polyps or fragments, and the sum of volume over the initial volume of the beaker was considered the total sample volume. Then, the zooxanthellae extracted were subsequently disassociated from the zoantharian tissues by mechanical maceration and homogenizing. The extracted material was fixed in Lugol 10\% and examined using a Leica binocular microscope and Fuchs Rosenthal counting chambers at a total of six subsamples of the homogenized material. The cell densities of zooxanthellae were expressed per sample volume (cells $\mathrm{cm}^{-3}$ ), as described by Costa et al. (2013).

\section{HISTOLOGICAL ANALYSIS}

After 12 hours of fixation, the samples of the zoantharian underwent continuous washes with water for a time equal to the period of fixation. After decalcification according to Fujii and Reimer (2011), the samples were then dehydrated in a series of ETOH (70\%, 80\%, 90\%, and 100\%) and cleared in xylene, embedded in paraffin, sectioned at $5-7 \mu \mathrm{m}$, and stained with hematoxylin and eosin (H\&E). We prepared and examined a total of 10 slides from each fragment stained with H\&E. All slides were analyzed using a Leica trinocular microscope DM 2500 , for the integrity and organization of the tissue layers, the integrity of the constituent cells of each layer, presence, and appearance of reproductive structures, presence of associated microorganisms and appearance of the symbiont zooxanthellae.

\section{STATISTICAL ANALYSIS}

Statistical analysis were performed using STATISTICA 7.0 software, at a $5 \%$ level of significance. The homoscedasticity and normality of the variances of all data sets were confirmed using the Levene and Shapiro tests, respectively.

ANOVA and Tukey HSD post hoc tests were applied to compare the mean differences densities 
of colonies with necrosis collected among the five localities monitored in 2008. Furthermore, they were applied to compare the mean differences of zooxanthellae densities on apparently healthy and black-spot colonies collected during the period from September 2008 to May 2009, and from February to December 2013.

The Student's t-test was used to test differences in mean zooxanthellae densities in the dry and rainy seasons, and between apparently healthy colonies and those showing black-spots. Pearson's correlation test was used to correlate environmental variables (sea surface temperature, salinity, dissolved oxygen, suspended material, and rainfall index) with zooxanthellae variables and to analyze the relationship between the frequency of disease appearance and the numbers of colonies (according to Kuta and Richardson, 1996).

\section{RESULTS}

\section{LATITUDINAL EXTENSION OF THE DISEASE}

Table 1 presents information on the length, width and frequency of lesions in the colonies inspected on the studied reefs, as well as information on the environmental conditions of the studied areas.

Some degraded lesions had diameters between 1.0 and $5.0 \mathrm{~cm}$, but degraded lesions with diameters up to $40.0 \mathrm{~cm}$ were observed on the reefs at Búzios - RN (Figure 1). The surveys at different localities demonstrated that the necrotizing disease of $P$. caribaeorum manifests itself in diverse forms, affecting both the margins and surface of the colonies. However, no significant differences were observed between the different localities visited regarding the numbers and percentages of colonies demonstrating necrosis $(F=1.500 ; d f=4 ; p=0.21$;

Table 1. Quantitative evaluations of the parameters related to the appearance of necrosis in $P$. caribaeorum during the months of March and April/2008.

\begin{tabular}{|c|c|c|c|c|c|}
\hline \multirow{2}{*}{$\begin{array}{l}\text { Parameters related to the } \\
\text { appearance of necrosis }\end{array}$} & \multicolumn{5}{|c|}{ Studied reefs } \\
\hline & PI-PB & CB-PB & CA-PB & PG-PE & BZ-RN \\
\hline Number of monitored colonies & 50 & 50 & 50 & 50 & 50 \\
\hline $\begin{array}{l}\text { Numbers and percentages of } \\
\text { colonies demonstrating necrosis }\end{array}$ & $17(34 \%)$ & $34(68 \%)$ & $12(24 \%)$ & $37(74 \%)$ & $25(50 \%)$ \\
\hline Colony lengths (cm) & $3-700(303.3)$ & $20-450(122.6)$ & $10-490(162.6)$ & $36-317(160.2)$ & $16-1500(1095.7)$ \\
\hline Colony widths (cm) & $5-435(175.3)$ & $4-82(37.0)$ & $7-230(63.5)$ & $7-137(49.1)$ & $10-300(221.8)$ \\
\hline Colony areas $\left(\mathrm{m}^{2}\right)$ & $0.01-30.45(0.82)$ & $0.03-3.69(0.36)$ & $0.01-11.27(0.38)$ & $0.03-4.34(0.43)$ & $0.02-45.0(1.36)$ \\
\hline $\begin{array}{l}\text { Quantities of areas with degraded } \\
\text { lesions }\end{array}$ & 85 & 79 & 26 & 122 & 70 \\
\hline $\begin{array}{l}\varnothing \text { of the areas with degraded lesions } \\
(\mathrm{cm})\end{array}$ & $1-8(3.4)$ & $1-10(3.7)$ & $2-19(5.1)$ & $0.5-14(3.9)$ & $1.5-40.0(8.7)$ \\
\hline Frequencies of degraded lesions & 1.7 & 1.6 & 0.5 & 2.4 & 5.8 \\
\hline Quantities of black-spots & 174 & 19 & 17 & 85 & 10 \\
\hline$\varnothing$ of the black-spots (cm) & $0.5-5(2.2)$ & $1-7(2.8)$ & $1-3(1.6)$ & $0.5-4(1.4)$ & $1-8(2.4)$ \\
\hline Frequencies of the black-spots & 3.5 & 0.4 & 0.3 & 1.7 & 0.2 \\
\hline $\begin{array}{l}\text { Quantity of open wounds at the } \\
\text { colony edges }\end{array}$ & 34 & 40 & 14 & 90 & 70 \\
\hline $\begin{array}{l}\text { Frequency of open wounds at the } \\
\text { colony edges }\end{array}$ & 0.3 & 0.1 & 0.2 & 3.3 & 0.2 \\
\hline $\begin{array}{l}\text { Quantities of black-spots at the } \\
\text { colony edges }\end{array}$ & 16 & 0,0 & 11 & 164 & 0,0 \\
\hline $\begin{array}{l}\text { Frequency of black-spots at the } \\
\text { colony edges }\end{array}$ & 0.7 & 0.8 & 0.3 & 1.8 & 1.4 \\
\hline Sea surface temperature & 31 & 30 & 30 & 32 & 31 \\
\hline Salinity & 35 & 36 & 35 & 35 & 36 \\
\hline
\end{tabular}




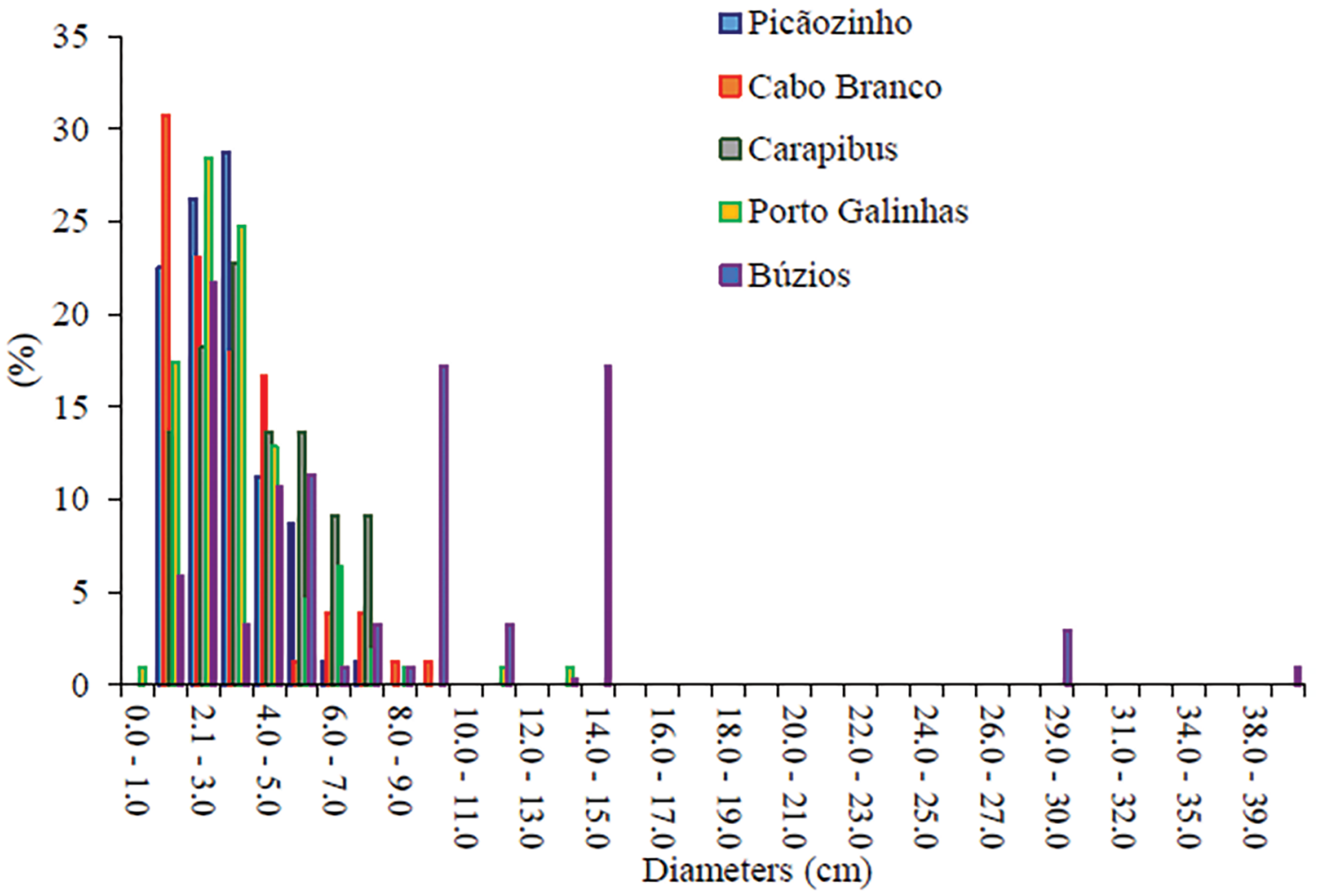

Figure 1. Diameter classes $(\mathrm{cm})$ of the necrotic areas of Palythoa caribaeorum colonies during the months of March and April of 2008.

Table 1). Disease prevalence was correlated with colony numbers at the three sites (Picãozinho - PB, Porto de Galinhas - PE, and Búzios - RN), suggesting similarities in the conditions of those habitats. The reefs at Carapibus - PB, and Picãozinho - PB, however, presented random lesions showing more favorable habitat conditions for P. caribaeorum.

\section{MONITORING OF THE DISEASE ON REEFS AT CABO BRANCO}

Monthly monitoring of the reefs at Cabo Branco demonstrated the presence of bleached colonies during almost all two monitoring periods (except in May 2009). During the first monitoring period, colonies with open wounds were encountered in November 2008, February 2009 and from April to May 2009, but no massive occurrence episodes were observed; but during the second monitoring period (from February 2013 to March 2014) colonies with open wounds were found in all studied months (Table 2).
The water temperatures at those dates demonstrated only regular seasonal cycles, with maximum values from November 2008 to March 2009, and in February and March of the years 2013 and 2014; salinity values were highest from December 2008 to February 2009, February 2013 and March 2013 , during the first rains. The rainy period extended from February to May 2009, with maximum rainfall occurring in April and May (540.4 mm and 521.2 $\mathrm{mm}$, respectively), and from May to September 2013 (except August), with maximum rainfall occurring in June and July $2013(448.0 \mathrm{~mm}$ and $460.5 \mathrm{~mm}$, respectively). The values of dissolved oxygen and suspended material demonstrated regular monthly variations, without any visible relationship to local climatic patterns (Table 2). Thermal anomalies during the study months were within the normal range for the region.

The key descriptors of the necrotizing disease are presents in Table 3. This disease first manifests itself as a dark stain (black), that can be round or 
Table 2. Monthly monitoring of the necrotizing disease in Palythoa caribaeorum colonies on the reefs at Cabo Branco, João Pessoa - PB, Brazil.

\begin{tabular}{|c|c|c|c|c|c|c|}
\hline Months & $\begin{array}{l}\text { Colonies with } \\
\text { open wounds }\end{array}$ & SST (OC) & $\mathrm{s}$ & $\mathrm{RI}(\mathrm{mm})$ & $\mathrm{SM}\left(\mathrm{mg} \mathrm{L}^{-1}\right)$ & $\mathrm{DO}\left(\mathrm{mg} \mathrm{L}^{-1}\right)$ \\
\hline Sep/08 & & 28.0 & 36.0 & 86.7 & 12.35 & 7.74 \\
\hline Oct/08 & & 29.4 & 38.0 & 44.2 & 18.70 & 7.70 \\
\hline Nov/08 & $x$ & 30.0 & 38.0 & 5.0 & 28.77 & 9.40 \\
\hline Dec/08 & & 31.7 & 39.0 & 57.7 & 9.97 & 11.10 \\
\hline Jan/09 & & 31.0 & 40.0 & 57.7 & 20.50 & 7.35 \\
\hline Feb/09 & $\mathrm{X}$ & 31.4 & 39.0 & 260.6 & 13.03 & 7.45 \\
\hline Mar/09 & & 30.0 & 37.0 & 129.8 & 13.57 & 8.62 \\
\hline Apr/09 & $x$ & 28.0 & 37.0 & 540.4 & 14.10 & 8.39 \\
\hline May/09 & $x$ & 27.5 & 33.0 & 521.2 & 13.07 & 6.83 \\
\hline Feb/13 & $x$ & 30.5 & 40.0 & 61.8 & 11.22 & 7.12 \\
\hline Mar/13 & $x$ & 32.5 & 40.0 & 39.0 & 13.12 & 7.26 \\
\hline Apr/13 & $x$ & 26.6 & 37.4 & 17.5 & 14.26 & 8.36 \\
\hline May/13 & $x$ & 26.0 & 36.0 & 268.9 & 15.22 & 8.12 \\
\hline Jun/13 & $x$ & 28.8 & 33.0 & 448.0 & 16.54 & 7.36 \\
\hline $\mathrm{Jul} / 13$ & $\mathrm{X}$ & 28.5 & 34.1 & 460.5 & 17.32 & 7.22 \\
\hline Aug/13 & $x$ & 27.4 & 35.3 & 114.0 & 32.78 & 8.09 \\
\hline Sep/13 & $x$ & 27.2 & 35.6 & 286.9 & 13.25 & 8.12 \\
\hline Oct/13 & $x$ & 30.2 & 36.8 & 8.7 & 21.32 & 8.24 \\
\hline Nov/13 & $x$ & & & & 26.4 & 8.89 \\
\hline $\mathrm{Dec} / 13$ & $x$ & 26.7 & 36.8 & 35.6 & 10.32 & 9.36 \\
\hline Jan/14 & $x$ & 29.7 & 37.3 & 81.6 & 15.45 & 9.84 \\
\hline Feb/14 & $x$ & 31.5 & 36.6 & 111.2 & 16.56 & 7.54 \\
\hline $\mathrm{Mar} / 14$ & $x$ & 31.8 & 35.0 & 150.5 & 14.8 & 7.22 \\
\hline
\end{tabular}

SST = Sea surface temperature; $\mathrm{S}=$ Salinity; $\mathrm{RI}$ = Rainfall index; $\mathrm{SM}=$ Suspended material; DO = Dissolved oxygen (greatest values in bold).

oblong-elliptic to cylindrical on the surfaces of the colonies; the tissues then become progressively pallid (indicating polyp bleaching), followed by polyp deformation (Figures $2 \mathrm{~A}$ and $2 \mathrm{~B}$ ). Further disease development eventually leads to coenenchyme degradation and exposure of the substrate. Tissue loss appears diffusely, including at the edges of the colony, and mucus production becomes severely reduced as the condition progresses. Alterations of polyp morphology (Figures $2 \mathrm{~A}, 2 \mathrm{~B}$, and $2 \mathrm{C}$ ) and their color patterns could also be observed with the advance of the disease (Figures 2C and 2D).

The progression of the necrotizing disease in colonies of the zoantharian Palythoa caribaeorum on coastal reefs in northeastern Brazil resulted in tissue loss exposing large areas of the substrate, which were subsequently colonized by macroalgae and other organisms. Patches of diseased colonies with apparently healthy coloration and recovering colonies (after six months) still showed areas of tissue loss (Figures 2E and 2F).

Microscopic analysis of samples of degraded tissue of $P$. caribaeorum from the reefs at Cabo Branco revealed large quantities of cyanobacteria similar in morphology to those in the genus Phormidium, ciliated protists of the genus Euplotes (Figure 3) and many bacteria and diatoms.

\section{ANALYSIS OF ZOOXANTHELLAE}

The mean populations densities of zooxanthellae were significantly higher in apparently healthy colonies $\left(5.2 \pm 3.1 \times 10^{6} \mathrm{~cm}^{-3}\right.$ and $\left.8.14 \pm 1.43 \times 10^{6} \mathrm{~cm}^{-3}\right)$ and significantly lower in colonies showing blackspots $\left(2.7 \pm 1.4 \times 10^{6} \mathrm{~cm}^{-3}\right.$ and $\left.3.34 \pm 0.81 \times 10^{6} \mathrm{~cm}^{-3}\right)$ $(t=4.2524 ; d f=67 ; p=0.001$ and $t=28.44850 ; d f=190$; $p=0.001$ for the first and second period, respectively). 
Table 3. Necrotic characteristics of diseased colonies of Palythoa caribaeorum on coastal reefs in northeastern Brazil during the years of 2008 and 2009 (*Adapted from Acosta, 2001 and based on the observations of the present study).

\begin{tabular}{|c|c|}
\hline Parameter considered & Description* \\
\hline $\begin{array}{l}\text { Quantities of polyps in the adjacent } \\
\text { coenenchyme }\end{array}$ & One or a few. \\
\hline $\begin{array}{l}\text { Shapes of the polyps in the adjacent } \\
\text { coenenchyme }\end{array}$ & Oblong, dilated and deformed (Figures $2 \mathrm{~A}$ and $2 \mathrm{~B}$ ). \\
\hline $\begin{array}{l}\text { Color of the polyps in the adjacent } \\
\text { coenenchyme }\end{array}$ & Bleached to light blue (Figures $2 \mathrm{~B}, 2 \mathrm{C}$ and 2D). \\
\hline Color and shape of the affected area & $\begin{array}{l}\text { During initial stages, the affected area appears as a dark stain (black), that can be round or } \\
\text { oblong elliptic to cylindrical. The lesions along the colony edges can extend for more than } \\
20 \mathrm{~cm} \text {. The interior of the polyp is always dark (black). }\end{array}$ \\
\hline Mucus production & $\begin{array}{l}\text { Very little, in extreme cases can be extremely reduced - clearly indicating a severe stress } \\
\text { situation affecting the entire colony. }\end{array}$ \\
\hline Location in the colony & $\begin{array}{l}\text { Diffuse, from one necrotic area per colony to various. Indiscriminate, affecting the center } \\
\text { or the edges of the colonies. }\end{array}$ \\
\hline Disease progress & $\begin{array}{l}\text { Very rapid. The colony tissues become progressively paler (bleaching of the polyps), } \\
\text { followed by deformation, retraction, degradation of the coenenchyme, and exposure of } \\
\text { the substrate. }\end{array}$ \\
\hline Characteristics of the necrosis & $\begin{array}{l}\text { Foul smell, of putrefying tissue. Dark-gray, occasionally purplish on the edges. Loss of } \\
\text { adherence of the colony to the substrate in affected areas. Many bacteria (Vibrio), fungi, } \\
\text { protozoans (Euplotes), diatoms and even Cyanobacteria of the genus Phormidium. }\end{array}$ \\
\hline Most representative time of the year & $\begin{array}{l}\text { End of the Austral summer and the beginning of the seasonal rainy period (February/ } \\
\text { March/April), when mature gonads and egg release were also observed. }\end{array}$ \\
\hline Post-lesion effects & $\begin{array}{l}\text { Loss of tissue at rates of } 57-85 \mathrm{~cm} 2 / \text { day. Disappearance of tissue through predation or } \\
\text { hydrodynamic erosion. Exposure of the substrate in the affected areas for various months. } \\
\text { Colonization of the substrate in the lesioned areas by other organisms such as algae and } \\
\text { Zoanthus sociatus (Figures } 2 \mathrm{E} \text { and } 2 \mathrm{~F} \text { ). Colony recuperation is slow, initiating after } 6 \text { to } 9 \\
\text { months. }\end{array}$ \\
\hline $\begin{array}{l}\text { Quantities of the necrotic areas per } \\
\text { colony }\end{array}$ & $\begin{array}{l}\text { Variable from location to location, suggesting local influences. The diameters of the } \\
\text { lesions can vary from less than } 1 \mathrm{~cm} \text { to more than } 60 \mathrm{~cm}(2826 \mathrm{~cm} 2) \text {. In certain cases, up to } \\
80 \% \text { of the colony can be lost, but total mortality of the colony was never observed. }\end{array}$ \\
\hline
\end{tabular}

The zooxanthellae in apparently healthy colonies showed variable population densities during the study period, with significantly higher values in September $2008\left(9.0 \pm 1.1 \times 10^{6} \mathrm{~cm}^{-3}\right)$ and significantly lower values in December $2008\left(3.1 \pm 0.4 \times 10^{6} \mathrm{~cm}^{-3}\right)$ ( $F=11.43109 ; d f=28 ; p=0.001$; and the Tukey HSD test; Figure $4 \mathrm{~A}$ ).

In the second period the population densities were significantly higher in October/2013 (9.31 \pm $\left.0.53 \times 10^{6} \mathrm{~cm}^{-3}\right)$ and significantly lower in March 2013 $\left(6.46 \pm 1.44 \times 10^{6} \mathrm{~cm}^{-3}\right)(F=41.2472 ; d f=5 ; p=0.001 ;$ and the Tukey HSD test; Figure 4B).

Colonies with black-spots did not demonstrate significant variations in the zooxanthellae densities during the first studied months. But on the second period of monitoring the population densities in colonies with black-spots were significantly higher in July/2013 $\left(4.09 \pm 0.63 \times 10^{6} \mathrm{~cm}^{-3}\right)$ and significantly lower in March $2013\left(2.05 \pm 0.71 \times 10^{6} \mathrm{~cm}^{-3}\right)$ $(F=31.30068 ; d f=5 ; p=0.001$; and the Tukey HSD test; Figure 4B).

The presence of black-spots on the colonies reduced zooxanthellae densities, with the months of September and November 2008, March 2009 and March 2013 showing the greatest statistically significant reductions (in relation to healthy colonies), varying from $72.6 \%$ in September 2008 to $74.2 \%$ in March 2009 ( $F=3.5736 ; d f=24 ; p=0.01$; and the Tukey HSD test; Figure 4A). In the second period of monitoring, the greatest reductions of populations densities range from 59.3\% in October 2013 to $65.5 \%$ in March 2013 ( $F=11.92699 ; d f=5 ; p=0.0001$; and the Tukey HSD test; Figure 4B).

The mean zooxanthellae densities in apparently healthy colonies and colonies with black-spots collected in the second period of the study did not 


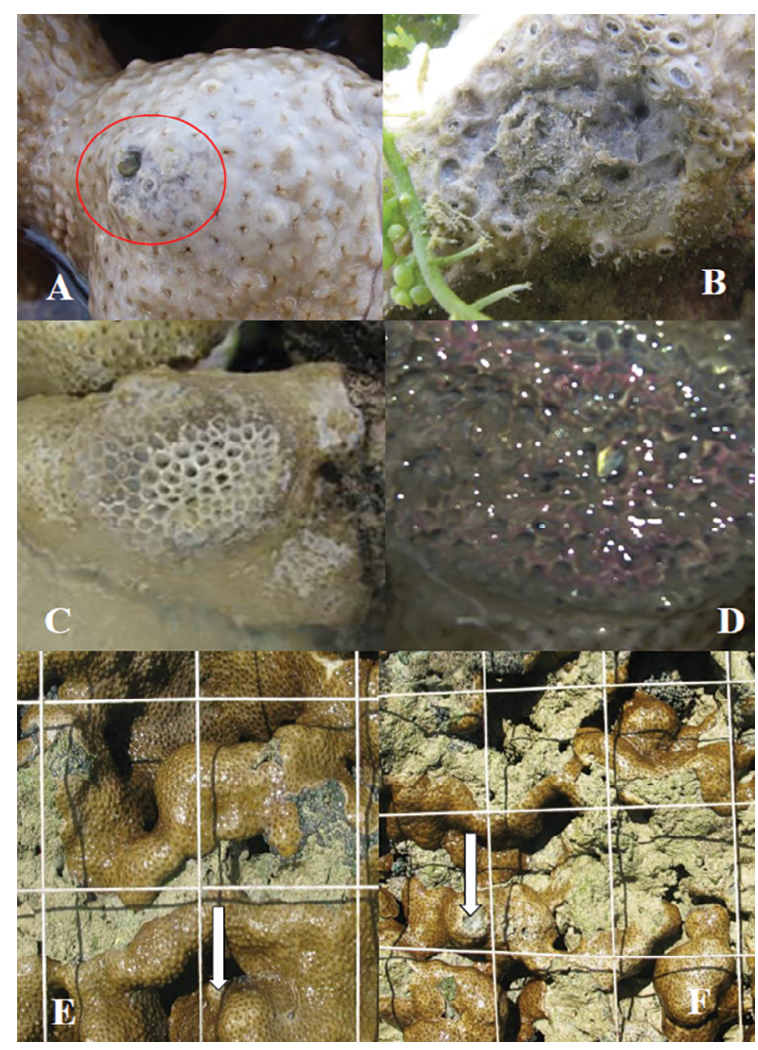

Figure 2. Necrotizing disease observed in colonies of the zoanthid Palythoa caribaeorum on the coastal reefs of northeastern Brazil during the Austral summers of 2008 and 2009 (A- details of colony with black spot; B-D - details of the alterations of polyp morphology and their color patterns, surrounding the areas of tissue loss; C,D alterations in the color pattern in necrotic areas; $\mathrm{E}, \mathrm{F}$ - tissue loss and exposure of the substrate with patches of the colonies with apparent healthy coloration, and recovering colonies - after six months - still showing open wounds - white arrow).

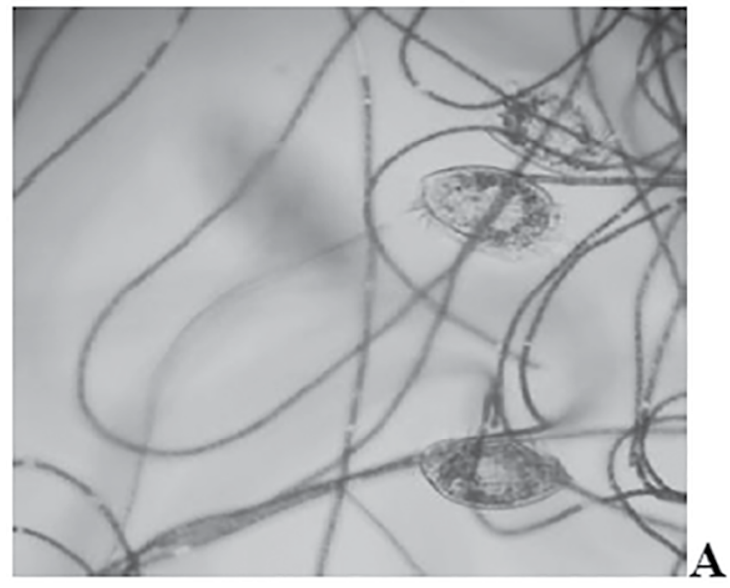

suggest significant differences between the dry and rainy seasons (Table 4). Cell densities were reduced by more than $50 \%$ during climatic seasons in colonies with black-spots, but the differences among dry and rainy periods were not significant (Table 4).

On the other hand, in the second period of the monitoring (February to December of 2013), such differences were significant (Table 5), and the reductions of cell densities were significantly higher during the dry season and significantly lower during the rainy season in colonies with black-spots (Table 5). Analysis of colony conditions revealed that zooxanthellae densities were significantly higher in healthy colonies and significantly lower in colonies with black-spots (Table 6).

More than one environmental variable was observed to have significant influences on zooxanthellae parameters. Among apparently healthy colonies $(\mathrm{HC})$, the sea surface temperature and surface water salinity significantly influenced zooxanthellae densities. The seasonal rainfall and water salinity significantly influenced zooxanthellae's densities in colonies with black-spots (Table 7). Sea surface temperature had no apparent influence on the zooxanthellae densities (either among apparently healthy colonies or those showing blackspots) - demonstrating that this environmental variable alone is not associated with the appearance of the necrotizing disease in Palythoa caribaeorum on the reefs at Cabo Branco. Of all the environmental

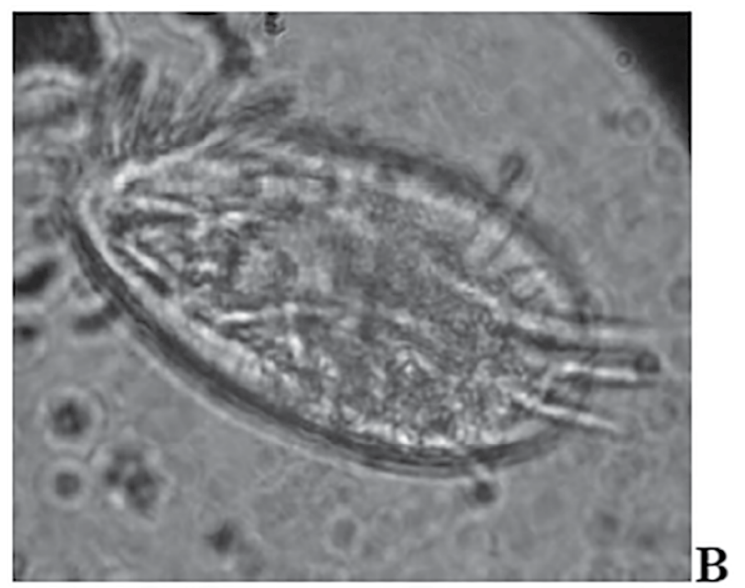

Figure 3. Cyanobacteria of the genus Phormidium (A) and ciliates of the genus Euplotes (B) encountered in the areas of tissue loss of $P$. caribaeorum on the reefs at Cabo Branco, João Pessoa, PB, Brazil. 

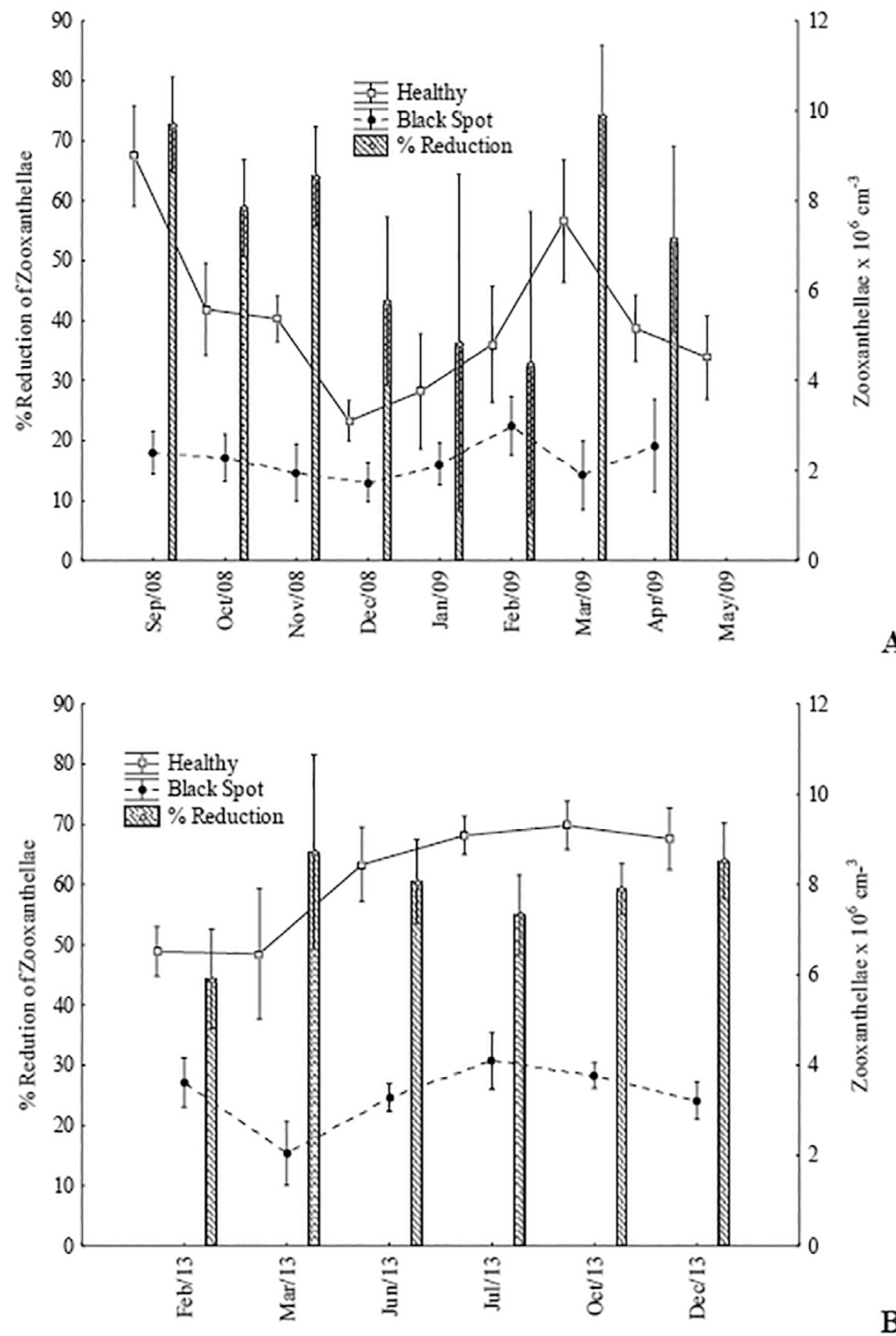

Figure 4. Average monthly densities of zooxanthellae on healthy and black spots colonies of Palythoa caribbaeorum and mean percentage (\%) reductions of zooxanthellae in colonies with black spots, on the reefs at Cabo Branco, João Pessoa-PB, Brazil, during the period between September/2008 and May/2009 (A), and during the period between February to December/2013 (B).

parameters analyzed, only the water salinity and the rainfall index significantly influenced the reduction of zooxanthellae of colonies with black-spots about the apparently healthy colonies during the first monitoring period (Table 7).

\section{HISTOLOGICAL ANALYSIS}

Histological preparations showed tissue layer organization, the mesenterium (septum), and the polyps' retractor muscles in healthy colonies 
Table 4. Parameters of the zooxanthellae associated with Palythoa caribaeorum on the reefs at Cabo Branco, João Pessoa - PB, Brazil.

\begin{tabular}{lccccc}
\hline \multirow{2}{*}{$\begin{array}{l}\text { Parameters of the } \\
\text { zooxanthellae }\end{array}$} & \multicolumn{2}{c}{ Climate seasons } & \multicolumn{3}{c}{ Student $\boldsymbol{t}$-Test } \\
\cline { 2 - 6 } & Dry & Rainy & $\boldsymbol{T}$ & $\boldsymbol{d f}$ & $\boldsymbol{P}$ \\
\hline Density (HC) & $5.1 \pm 1.9$ & $5.7 \pm 1.6$ & -0.915 & 35 & 0.36 \\
Density (BS) & $2.2 \pm 0.6$ & $2.2 \pm 0.9$ & 0.253 & 30 & 0.80 \\
\% Reduction (BS) & $51.1 \pm 20.8$ & $65.4 \pm 16.4$ & -1.667 & 30 & 0.10 \\
\hline
\end{tabular}

Density $=$ cells $\times 10^{6} \mathrm{~cm}^{-3} ; \mathrm{HC}=$ Healthy colonies; $\mathrm{BS}=$ Black-spots (Data collected in the second period of study).

Table 5. Parameters of the zooxanthellae associated with Palythoa caribaeorum on the reefs at Cabo Branco, João Pessoa - PB, Brazil.

\begin{tabular}{lccccc}
\hline \multirow{2}{*}{$\begin{array}{l}\text { Parameters of the } \\
\text { zooxanthellae }\end{array}$} & \multicolumn{2}{c}{ Climate seasons } & \multicolumn{3}{c}{ Student $\boldsymbol{t}$-Test } \\
\cline { 2 - 6 } & Dry & Rainy & $\boldsymbol{T}$ & $\boldsymbol{d f}$ & $\boldsymbol{P}$ \\
\hline Density (HC) & $9.2 \pm 0.6$ & $7.6 \pm 1.6$ & -5.67248 & 94 & 0.0001 \\
Density (BS) & $3.5 \pm 0.4$ & $3.3 \pm 0.9$ & -1.33783 & 94 & 0.0001 \\
$\%$ Reduction (BS) & $61.6 \pm 5.7$ & $56.3 \pm 12.7$ & -2.22709 & 94 & 0.0001 \\
\hline
\end{tabular}

Density = cells $\times 10^{6} \mathrm{~cm}^{-3} ; \mathrm{HC}=$ Healthy colonies; $\mathrm{BS}=$ Black-spots (Data collected in the second period of study).

Table 6. Zooxanthellae of healthy colonies and colonies with black-spot of the Palythoa caribaeorum on the reefs at Cabo Branco, João Pessoa - PB, Brazil.

\begin{tabular}{lccccc}
\hline Parameters of the & \multicolumn{2}{c}{ Colonies conditions } & \multicolumn{3}{c}{ Student $\boldsymbol{t}$-Test } \\
\cline { 2 - 6 } zooxanthellae & Healthy & Black-spot & $\boldsymbol{t}$ & $\boldsymbol{d f}$ & $\boldsymbol{P}$ \\
\hline *Density $\left(\mathrm{cel} \times 10^{6} \mathrm{~cm}^{-3}\right)$ & $5.2 \pm 3.1$ & $2.7 \pm 1.4$ & 4.252 & 67 & 0.0001 \\
${ }^{* *}$ Density $\left(\mathrm{cel} \times 10^{6} \mathrm{~cm}^{-3}\right)$ & $8.1 \pm 1.4$ & $3.3 \pm 0.8$ & 28.44850 & 190 & 0.0001 \\
\hline
\end{tabular}

*Monitoring form September/2008 to April/2009; **Monitoring from February to December 2013.

Table 7. Spearman correlations of environmental variables and the parameters of the zooxanthellae of Palythoa caribaeorum.

\begin{tabular}{|c|c|c|c|c|c|c|}
\hline \multirow{2}{*}{$\begin{array}{l}\text { Period of } \\
\text { monitoring }\end{array}$} & \multirow{2}{*}{$\begin{array}{l}\text { Parameters of the } \\
\text { zooxanthellae }\end{array}$} & \multicolumn{5}{|c|}{ Correlation coefficient for: } \\
\hline & & SST (OC) & $\mathbf{S}$ & DO (\%) & SM (mg L-1) & $\mathbf{R I}(\mathbf{m m})$ \\
\hline \multirow{3}{*}{2008 to 2009} & Density $(\mathrm{HC})$ & -0.14 & $-0.79^{*}$ & -0.32 & -0.00 & -0.05 \\
\hline & Density (BS) & -0.21 & $-0.40^{*}$ & -0.28 & -0.01 & $0.47^{*}$ \\
\hline & $\%$ of reduction (BS) & -0.06 & $-0.61^{*}$ & 0.03 & 0.26 & $-0.41^{*}$ \\
\hline \multirow{3}{*}{$\begin{array}{l}\text { February to } \\
\text { December } 2013\end{array}$} & Density $(\mathrm{HC})$ & $-0.29^{*}$ & $-0.40^{*}$ & $\mathrm{~N}$ & $\mathrm{~N}$ & 0.12 \\
\hline & Density (BS) & -0.20 & $-0.27^{*}$ & $\mathrm{~N}$ & $\mathrm{~N}$ & 0.08 \\
\hline & $\%$ of reduction (BS) & $\mathrm{N}$ & $\mathrm{N}$ & $\mathrm{N}$ & $\mathrm{N}$ & $\mathrm{N}$ \\
\hline
\end{tabular}

$\mathrm{HC}=$ Healthy colonies; BS = Colonies with black-spots; SST = Sea Surface Temperature; S = Salinity; DO = Dissolved Oxygen; SM = Suspended Material; RI = Rainfall Index; ${ }^{*} p<0.05 ; \mathrm{n}=32 ; \mathrm{N}=$ Not analyzed.

(Figure 5). During February and March of 2014, many male reproductive structures (Spermatogonia) were found on several of the slides analyzed, indicating that the samples were gathered in the reproductive period (Figure 6).

Clear differences were observed in tissue and cellular architecture between apparent health and black-spot samples. In apparently healthy samples, tissue epithelia and mesoglea were within normal limits (Figures 7A and 8A). In black-spot samples, we observed deterioration of retractor muscles, disruption of the tissue layers, damaged complete mesentery, damaged mesoglea, and damaged ectoderm (Figures $7 \mathrm{~B}$ and $8 \mathrm{~B}$ ). In contrast to apparently healthy samples, the histological features of black-spot samples showed a distinct inflammatory 


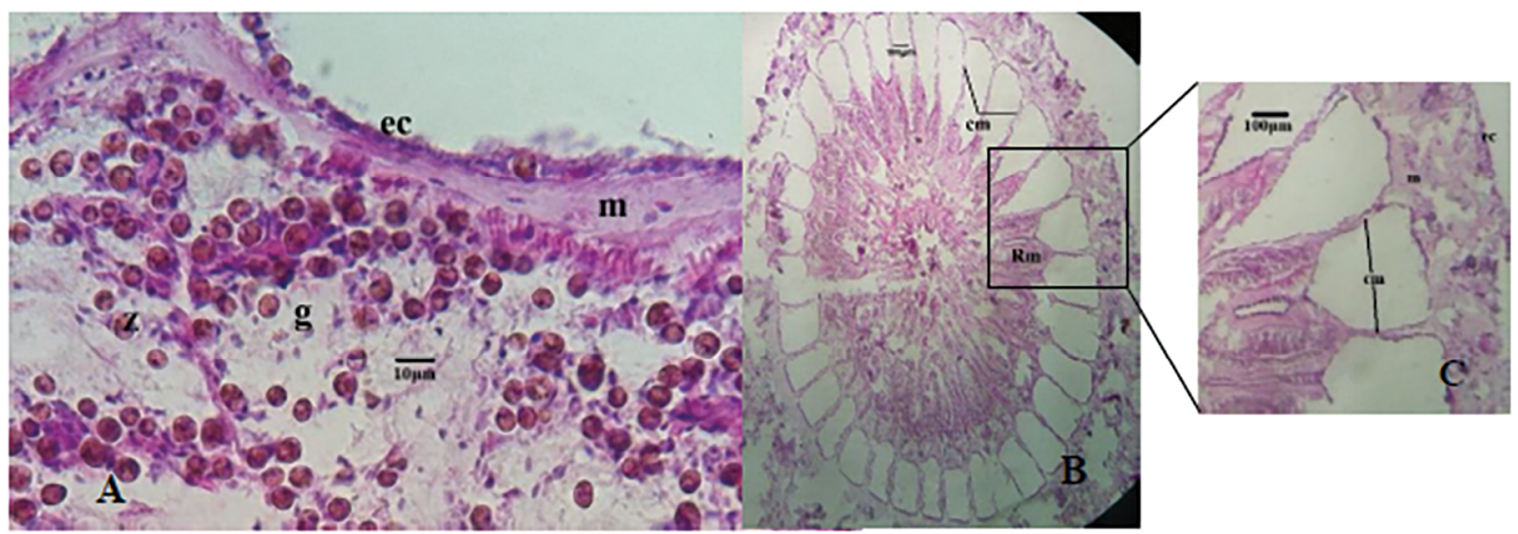

Figure 5. Cross section ( $5 \mu \mathrm{m}$ ) of a healthy sample of the zoanthid Palythoa caribaeorum collected on the reefs at Cabo Branco, Brazil, showing the tissue layers $(A)$ ( $e c=$ ectoderm; $g=$ gastroderm; $m=$ mesoglea; $z=$ zooxanthellae; $c m=$ complete mesentery; $R m=$ retractor muscle) and polyp structure (B-C).

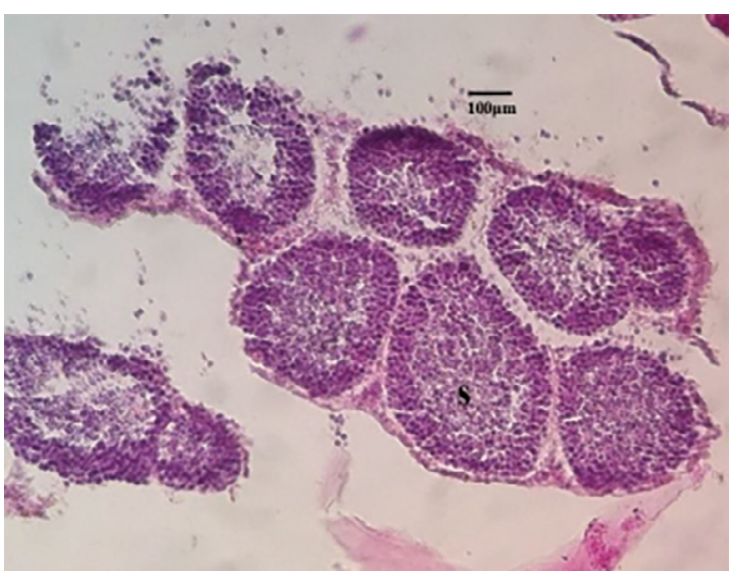

Figure 6. Cross section ( $5 \mu \mathrm{m})$ of polyp of Palythoa caribaeorum collected on the reefs at Cabo Branco, Brazil, showing a polyp male with Spermary (s).

and necrotizing component, hypertrophy, apoptosis of the gastrodermal cells, and apoptosis of the zooxanthellae (Figure 9). The histological analysis of black-spot samples showed a lack of polyp structure and fungal hyphae on mesoglea (Figure 10).

\section{DISCUSSION}

Diseases affecting reef organisms are becoming more prevalent and of more significant concern globally (Porte et al., 2011; Séré et al., 2016; Richardson, 1998; Palmer et al., 2011a, 2011b; TraylorKnowles et al., 2017). Symbiotic relationships are thrown into disarray when those diseases appear, and synchronicities are interrupted - alterations that can result in the death of those organisms and/or favor the development of other life forms (Gantar et al., 2011; Sudek et al., 2012; Sassi et al., 2015).

Disequilibria such as these have been documented globally for more than 30 years, but these phenomena have not yet been well studied in Brazil. Diseases involving corals and zoantharians have been documented (Acosta, 2001; FranciniFilho et al., 2008), but no detailed studies have been performed on Brazilian reefs, although cases of local bleaching (without excessively severe consequences for coral populations) have been reported (Migotto, 1997; Costa et al., 2001; Soares and Rabelo, 2014; Sassi et al., 2015; Banha et al., 2019). The necrotizing disease that affects specimens of Palythoa caribaeorum on Brazilian coastal reefs has attracted recent attention, however, because of its aggressiveness - drastically reducing colony sizes within just a few weeks.

The relationships between the areas affected by necrotizing disease and the number of black-spots on $P$. caribaeorum colonies observed during the present investigation indicate the aggressiveness of this disease. This disease has manifested itself very aggressively on the reefs of Búzios - RN and Porto de Galinhas - PE, as these two localities demonstrated the highest frequencies of necrosis. As zoantharians significantly contribute to reef productivity and trophic relationships, the appearance of this necrotizing disease will presumably have multiple direct or indirect repercussions on reef organisms that are dependent on these cnidarians during at least some stages of their life cycles. 


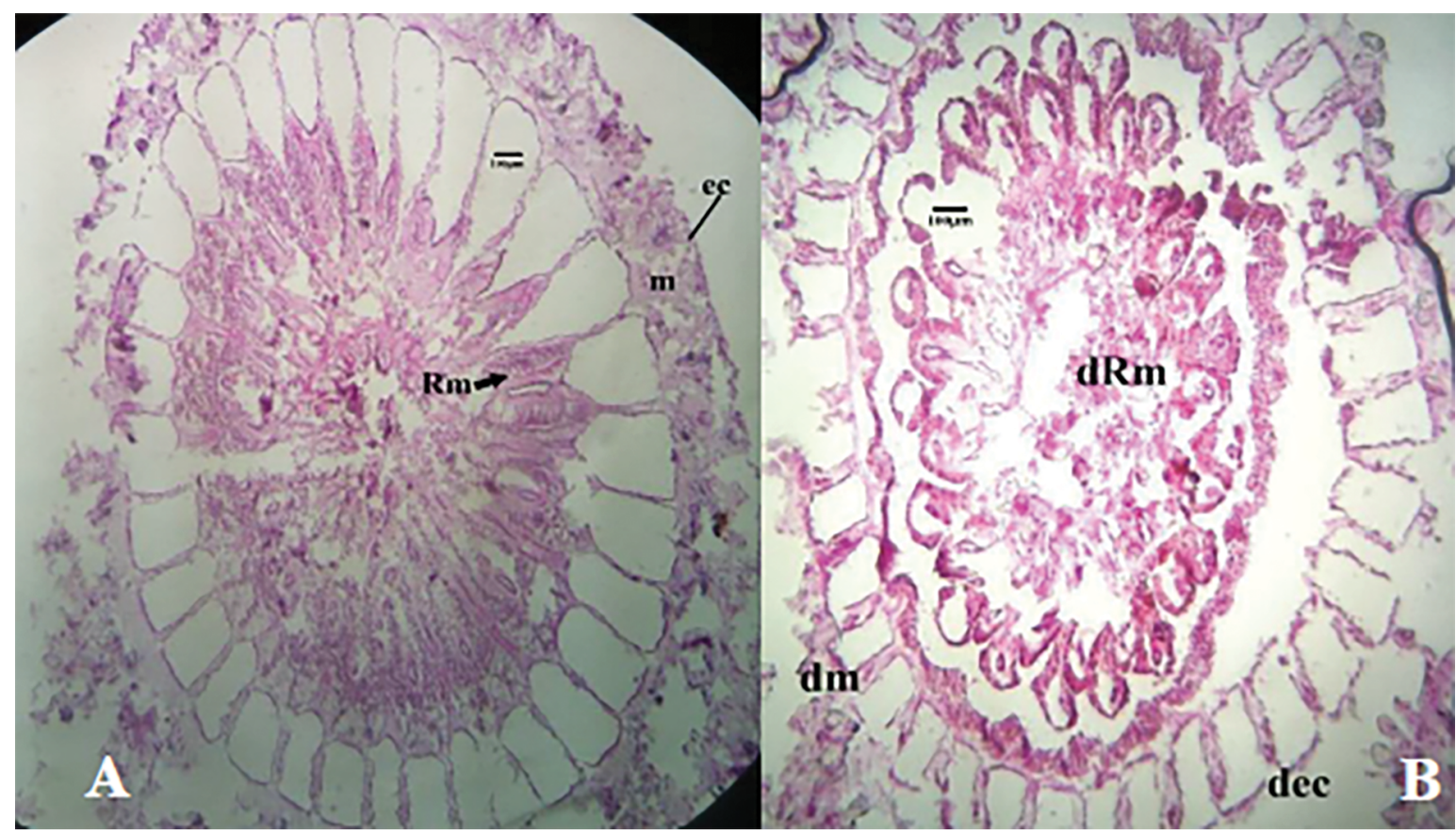

Figure 7. Cross-section $(5 \mu \mathrm{m})$ of polyp of $P$. caribaeorum at the actinopharynx demonstrating some major feature. (A) apparently healthy sample of $\mathrm{P}$. caribaeoruum ( $\mathrm{ec}=$ ectoderm; $\mathrm{m}=$ mesoglea; $\mathrm{Rm}=$ retractor muscle). (B) polyp sample with black spots, showing damaged mesoglea $(\mathrm{dm})$, damaged ectoderm $(\mathrm{dec})$, and damaged retractor muscles architecture $(\mathrm{dRm})$.

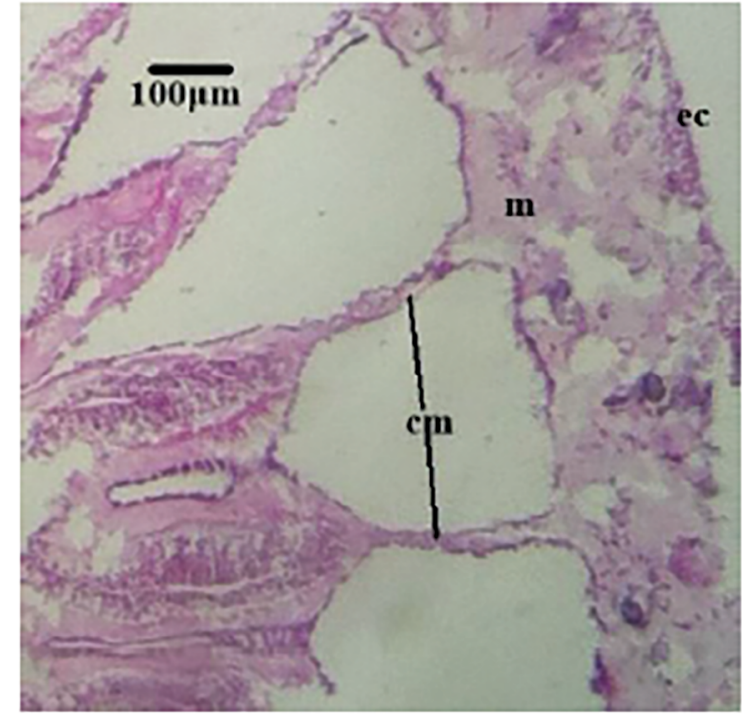

A

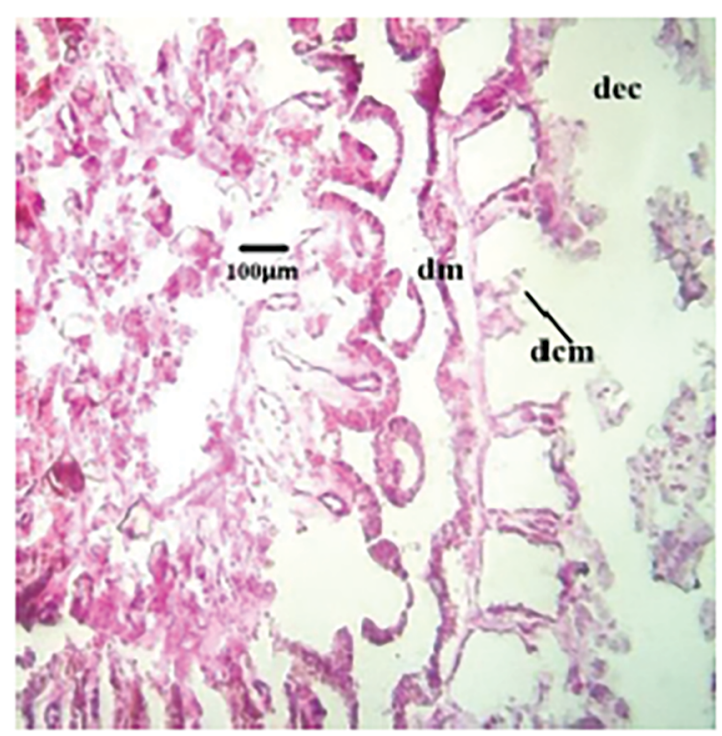

B

Figure 8. Cross-sections of Palythoa caribaeorum. $A=$ Well-preserved histological features of healthy sample: Note: complete mesentery (cm); mesoglea $(\mathrm{m})$, and ectoderm $(\mathrm{ec}) . \mathrm{B}=$ Histological features of the black-spot sample: Note: damaged complete mesentery (dcm); damaged mesoglea $(\mathrm{dm})$, and damaged ectoderm (dec).

The principal etiological agent of this disease is still unknown, although Acosta (2001) has suggested that the primary pathogen is a bacterium of the genus Vibrio, with fungi and other organisms being secondary invaders. This author speculated that the pathogen could be specific to $P$. caribaeorum, with that specificity being maintained by specific compounds produced by their symbiotic microbial assemblage. It is also possible 


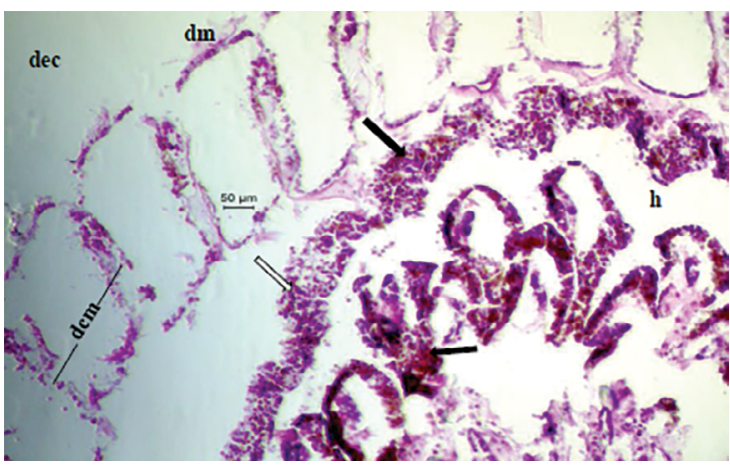

Figure 9. Necrotizing components observed in cross-sections of sample with black spot of Palythoa caribaeorum. Note: hypertrophy and apoptosis of the gastrodermal cells (white arrow); apoptosis of zooxanthellae (black arrow); damage complete mesentery $(\mathrm{dcm})$, damage mesoglea (dm), and damage ectoderm (dec).

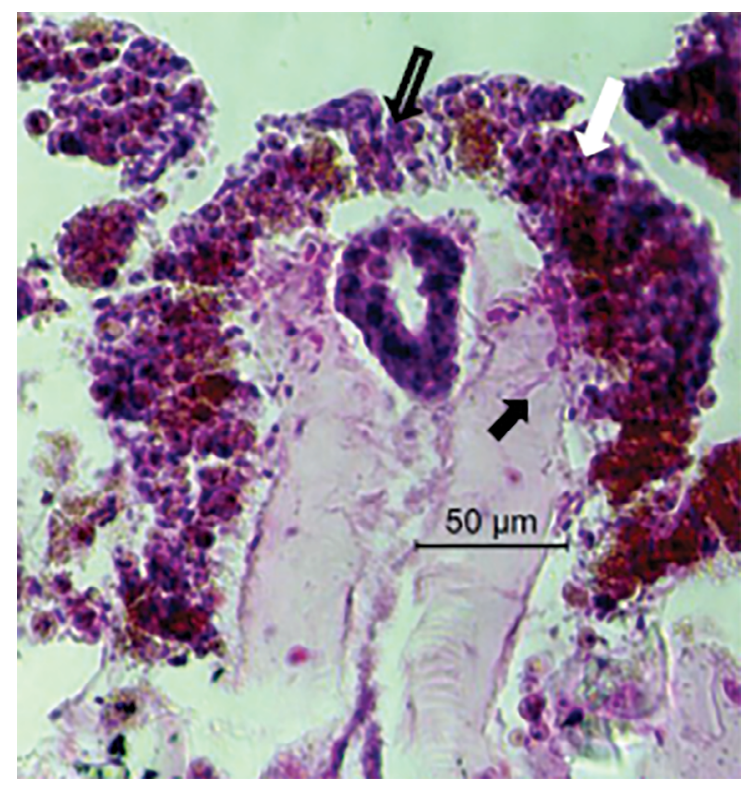

Figure 10. Cross-sections of sample with black spot of Palythoa caribaeorum. Note the proliferation and desquamation of gastrodermal cells (white arrow), fungal hyphae within the mesoglea (full black arrow), and destruction of the ectoderm (black arrow leaked).

that this disease is caused by a set of opportunist microorganisms that proliferate when environmental conditions are unfavorable, and the colonies become weakened. Sassi et al. (2015) demonstrated that pink colonies of Siderastrea stellata have significantly higher densities of viable bacteria in the tissue than the healthy colonies.

The cyanobacteria of the genus Phormidium, among other organisms, have commonly been found in the necrotic tissues of $P$. caribaeorum in Brazil (Acosta, 2001). Furthermore, Phormidium corallyticum is considered one of the principal components of the black band disease (BBD) in corals (Richardson et al., 2004; Barneah et al., 2007; Miller and Richardson, 2012; Kramarsky-Winter et al., 2014).

The necrotizing disease examined in the present study commences with the appearance of blackspots that rapidly evolve into open wounds indicating loss of immunity and destabilization of the symbiotic relationship between holobionts and their host. At this stage occurs a high infestation of opportunistic microorganisms that may include fungi, bacteria, diatoms, and ciliates (Euplotes) and the cyanobacteria of the genus Phormidium. Otherwise, colonies with black-spots also showed several histological damages in the mesoglea and the ectoderm and losses of the architecture of the retractor muscles as also observed in other studies of coral disease (Williams et al., 2011; Séré et al., 2016; Traylor-Knowles et al., 2017).

It was observed that the necrotizing phenomenon of Palythoa caribaeorum manifested itself with higher intensity during the Austral summer months (from February to April 2008), and the stress conditions created by a combination of high temperatures, high salinity and the arrival of the first heavy rainfall in the region were active factors in the appearance of this disease. Many records relating to the increase in water temperature and solar radiation as the main stressors of corals and can cause severe bleaching and mortality (either isolated or in tandem) (Porter et al., 2011; Palmer et al., 2011b; Kuehl et al., 2011).

As such, synergistic factors appear to be acting to promote the necrotizing disease observed in $P$. caribaeorum in Brazil. These zoantharians have been observed releasing eggs in the Austral summer in northeastern Brazil. The energetic resources channeled into reproduction could reduce the immunological strength of the colonies and destabilize the relationships between the zooxanthellae and their symbionts - thus favoring the proliferation of cyanobacteria and opportunist bacteria. Persistently high temperatures may aggravate this situation during that period and high solar radiation levels. A critical role for UV radiation in this phenomenon's appearance cannot be discarded but will require further investigation. 
The data acquired here indicated that persistently elevated temperatures and the arrival of the first summer rains act as destabilizing factors in terms of zoantharians' health and diminish their immunity. The synchronous actions of extreme meteorological conditions should be further investigated to determine their effects on the bleaching and disease onset in cnidarians on coral reefs in Brazil.

This necrotizing disease was not manifested in all of the research localities with the same intensity, and disease incidence was low in several areas (such as Carapibus - PB) in contrast to Picãozinho - PB, Porto de Galinhas - PE and Búzios - RN where the disease was very aggressive. These differences suggest that habitat conditions are essential factors in disease expression.

Two different groups of zooxanthellae (corresponding to clades $A$ and $C$ ) were identified in three different species of Brazilian zoantharians (Costa et al., 2013; Rabelo et al., 2015). The zoantharians P. caribaeorum was identified as hosting Symbiodinium goreaui C1, sensu LaJeunesse (LaJeunesse, 2001) (Costa et al. (2013); this zooxanthellae clade may be responsible for allowing $P$. caribaeorum to develop a cospecific compensation mechanism against actively aggressive stress factors (such as the necrotizing disease).

Costa et al. (2008) demonstrated that zooxanthellae from clade $\mathrm{C}$ in the coral Siderastrea stellata were associated with ecological plasticity and the ability to reverse bleaching. According to Rowan et al. (1997) and Glynn et al. (2001), the four lineages of Symbiodinium show different resistances to bleaching, in the order $A>B>C>D$. Some published reports indicate that the zooxanthellae of clade $C$ (hosted by coral and octocorals) show only moderate susceptibility to bleaching (Rowan et al., 1997; KarakoLampert et al., 2004). Furthermore, Costa et al. (2008) noted that the clade $C$ zooxanthellae of the coral $S$. stellata favor its rapid recuperation from bleaching events and other environmental disturbances - as could be the case with the hosted by the zoantharians P. caribaeorum.

During the appearance of this disease in the present study, total mortality was never observed in Palythoa, even in the most severe cases, with remnant fragments demonstrating resistance and survival and the capacity to recompose the colonies in six to nine months. This fact indicates that the zooxanthellae lineages hosted by this species had varying levels of resistance and resilience - that favored eventual colony reestablishment (Toller et al., 2001; LaJeunesse, 2002). Thus, zooxanthellae diversity has implications for local coral communities, providing the hosts with mechanisms for rapid adaptation to environmental changes (Rowan et al., 1997).

The loss of colony tissues due to the expansion of necrotic lesions provides colonization opportunities for other organisms. Colonization by diverse macroalgae, Zoanthus sociatus, and other benthic invertebrates was observed in numerous cases where older necrotic lesions were still recovering, indicating that the appearance of this disease destabilized the system and created opportunities for ecological succession. P. caribaeorum is a strong competitor for space, and once free of this disease; it begins to recuperate lost areas (Acosta, 2001).

The division of the $P$. caribaeorum colonies into various groups of polyps connected by fine basal coenenchyme usually occurs by fission (Acosta and Sammarco, 2000; Acosta, 2001). The isolation of portions of the affected tissue by either physical (the rupture of basal connections) or physiological (the absence of basal coenenchyme) mechanisms can prevent pathogen spreading (Acosta, 2001), and those portions will function as patches of disease resistance.

In the present study, these patches of disease resistance appeared most efficient when overall habitat conditions were favorable, as was the case of the reefs at Carapibus - PB, where the substrate is composed of very irregular blocks of rocks divided by fissures that create light and thermal conditions that promote the formation of vertical colonies. In other locations (such as Picãozinho - PB and Porto de Galinhas - PE), the level, eroded reef surface favors the formation of extensive horizontal colonies exposed to rigorous environmental conditions during low tides.

It should be pointed out that as many colonies are exposed during low tides, they are subjected to extended contact with the atmosphere and thus with wide variations in air temperatures, insolation, and osmotic changes during rainy periods. Therefore, it can be assumed that $P$. caribaeorum exhibits a high degree of ecological plasticity, allowing it to adapt and survive in highly unstable intertidal environments. 
Many authors have concluded that local anthropogenic factors, such as pollution and freshwater discharge (Salm et al., 2001) and the silting-over of coral colonies (Philipp and Fabricius, 2003), can provoke bleaching events. For example, Philipp and Fabricius (2003) evaluated the responses of scleractinian corals to silting-over for variable periods. They concluded that those colonies experienced damage (as measured by reductions of zooxanthellae densities and chlorophyll concentrations) when exposed to excessive sediment coverage for long periods.

Bleached colonies of $P$. caribaeorum were found during the two entire periods of monitoring (from 2008 to 2009, and from 2013 to 2014), suggesting constant stress conditions with severe losses of zooxanthellae in colonies with black-spots. Significant reductions in the population densities of zooxanthellae (reaching 70\%-90\%) were also observed in bleached coral colonies by Fitt et al. (2000), Costa et al. (2014), and others.

The appearance of frequent manifestations of necrosis during the last monitoring period suggest the permanent presence of the pathogen(s) and the potential for new massive episodes of this disease, especially if the stability of the symbiotic relationship between the zooxanthellae and zoantharians was again destabilized due to environmental stress or even reproductive events.

\section{CONCLUSION}

The black-spot disease that affected P. caribaeorum during the summer of 2008, 2013 and 2014 in northeastern Brazil reefs is recurrent and promotes significant changes in tissue organization of affected colonies, such as hyperplasia of the mesoglea, hypertrophy, apoptosis of the gastrodermal cells, apoptosis of the zooxanthellae and damage in complete mesenteries. The histological analysis also showed a lack of polyp structure and fungal hyphae on the mesoglea of all colonies affected.

These aspects demonstrate the aggressiveness of this disease, which can be observed by histological techniques, even in the early stages of infection. Although powerfully aggressive, the disease did not result in the complete death of $P$. caribaeorum since the species is highly resistant and can usually restore the colony in 6-9 months. The data also showed that the disease does not have direct relationships with global warming, as thermal variations in the study area were within their normal range. Therefore, this disease seems to be dependent on habitat conditions.

\section{ACKNOWLEDGMENTS}

We thank the "Conselho Nacional de Desenvolvimento Científico e Tecnológico" (grant $\mathrm{n}^{\circ}$ : 479979/2007-8; 480175/2009-8) and Fundação Grupo Boticário de Proteção à Natureza (grant n: 0954_20122) for their support. The authors also thank the anonymous reviewers by their important contributions.

\section{AUTHOR CONTRIBUTIONS}

C.F.C.S: Writing - original draft; Writing - review \& editing; Methodology; Supervision; Funding acquisition. R.S.: Writing - original draft; Writing - review \& editing; Supervision; Funding acquisition. G.M.F.: Writing - review \& editing; Methodology.

\section{REFERENCES}

Agência Executiva de Gestão das Água 2009. AESA. Available: http://www.aesa.pb.gov.br. Accessed April/2009

ACOSTA, A. \& SAMMARCO, P. W. 2000. Modes of asexual reproduction in the zoanthids Palythoa caribaeorum. In: Proceedings of the 9th International Coral Reef Symposium, 23-27 October, Bali, Indonesia, 9, 144.

ACOSTA, A. 2001. Disease in zoanthids: dynamics in space and time. Hydrobiologia, 460(1-3), 113-130.

ADDAD, J. \& MARTINS-NETO, M. A. 2000. Deforestation and coastal erosion: a case from East Brazil. Journal of Coast Research, 16(2), 423-431.

AMARAL, F. D., HUDSON, M. M., SILVEIRA, F. L., MIGOTTO, A. E., PINTO, S. M. \& LONGO, L. L. 2000. Cnidarians of Saint Peter and St. Paul Archipelago, Northeast Brazil. In: Proceedings of the 9th International Coral Reef Symposium, 23-27 October, Bali, Indonesia, 1, 567-572.

BANHA, T. N. S., CAPEL, K. C. C., KITAHARA, M. V., FRANCINI-FILHO, R. B., FRANCINI C. L. B, SUMIDAL, P. Y. G. \& MIES, M. 2019. LoW coral mortality during the most intense bleaching event ever recorded in subtropical Southwestern Atlantic reefs. Coral Reefs, 39, 515-21. DOI: https://doi.org/10.1007/s00338-019-01856-y

BARNEAH, O., BEN-DOV, E., KRAMARSKY-WINTER, E. \& KUSHMARO, A. 2007. Characterization of black band disease in Red Sea stony corals. Environmental Microbiology, 9(8), 1995-2006.

BOSCOLO, H. K. \& SILVEIRA, F. L. 2005. Reproductive biology of Palythoa caribbaeorum and Protopalythoa variabilis (Cnidaria, Anthozoa, Zoanthidea) from the southeastern coast of Brazil. Brazilian Journal of Biology, 65(1), 29-4.

CHIMETTO, L. A., BROCCHI, M., GONDO, M., THOMPSON, C. C., GOMEZ-GIL, B. \& THOMPSON, F. L. 2009. Genomic diversity of vibrios associated with the Brazilian coral Mussismilia hispida and its sympatric zoanthids (Palythoa caribaeorum, $\mathrm{Pa}$ lythoa variabilis and Zoanthus solanderi). Journal of Applied Microbiology, 106(6), 1818-1826. 
COSTA, C. F., AMARAL, F. D. \& SASSI, R. 2001. Branqueamento em Siderastrea stellata (Cnidaria, Scleractinia) da praia de Gaibu, Pernambuco, Brasil. Revista Nordestina de Biologia, 15(1), 15-22.

COSTA, C. F., SASSI, R., COSTA, M. A. J. \& BRITO, A. C. L. 2007. Recifes costeiros da Paraíba, Brasil: usos, impactos e necessidades de manejo no contexto da sustentabilidade. Gaia Scientia, 1(1), 37-45.

COSTA, F. C., SASSI, R. \& GORLACH-LIRA, K. 2008. Zooxanthellae genotypes in the coral Siderastrea stellata from coastal reefs in northeastern Brazil. Journal of Experimental Marine Biology and Ecology, 367(2), 149-152.

COSTA, C. F., SASSI, R., GORLACH-LIRA, K., LAJEUNESSE, T. C. \& FITT, W. K. 2013. Seasonal changes in zooxanthellae harbored by zoanthids (Cnidaria, Zoanthidea) from coastal reefs in northeastern Brazil. Pan-American Journal of Aquatic Sciences, 8(4), 253-264.

COSTA, C. F., SASSI, R., GORLACK-LIRA, K. \& DE LIMA, C. P. 2014. Pigmentation patterns of Siderastrea Stellata Verrill, 1868 (Cnidaria, Scleractinia) from coastal reefs in northeastern Brazil and its relation with zooxanthellae and other microsymbionts. Pan-American Journal of Aquatic Sciences, 9, 207-222.

FITT, W. K., MCFARLAND, F. K., WARNER, M. E. \& CHILCOAT, G. C. 2000. Seasonal patterns of tissue biomass and densities of symbiotic dinoflagellates in reef corals and relation to coral bleaching. Limnology and Oceanography, 45(3), 677-685.

FRANCINI-FILHO, R. B., THOMPSON, F. L., REIS, R. M., KAUFMAN, L. E. S., KIKUCHI, R. K. P. \& LEÃO, Z. M. A. N. 2008. Diseases leading to accelerated decline of reef corals in the largest South Atlantic reef complex (Abrolhos Bank, eastern Brazil). Marine Pollution Bulletin, 56(5), 1008-1014.

FUJII, T. \& REIMER, J. D. 2011 Phylogeny of the highly divergent zoanthid Family Microzoanthidae (Anthozoa, Hexacorallia) from the Pacific. Zoologica Scripta, 40, 418-431.

GANTAR, M., KACZMARSKY, L. T., STANIĆ, D., MILLER, A. W. \& RICHARDSON, L. L. 2011. Antibacterial Activity of marine and black band disease cyanobacteria against coral-associated bacteria. Marine Drugs, 9(10), 2089-2105.

GARRETT, P. \& DUCKLOW, H. 1975. Coral diseases in Bermuda. Nature, 253, 349-350.

GLYNN, P. W., MATÉ, J. L., BAKER, A. C. \& CALDERÓN, M. O. 2001. Coral bleaching and mortality in Panamá and Ecuador during the 1997-1998 El Niño-southern oscillation event: spatial/temporal patterns and comparisons with the 19821983 event. Bulletin of Marine Science, 69(1), 79-109.

HARVELL, C. D., JORDAN, E., MERKEL, S., RAYMUNDO, L., ROSENBERG, E., SMITH, G., WEIL, E. \& WILLIS, B. L. 2007. Coral disease: environmental change and the balance between coral and microbes. Oceanography, 20(1), 58-81.

KARAKO-LAMPERT, S., KATCOFF, D. J. \& ACHITUV, Y. 2004. Do clades of symbiotic dinoflagellates in scleractinian corals of the Gulf of Eilat (Red Sea) differ from those of other coral reefs? Journal of Experimental Marine Biology and Ecology, 311(2), 301-314.

KHUSHALI, P. M. \& PRADEEP, M. C. 2013. Brachycnemic zooxanthellate zoanthids (Cnidaria: Zoantharia) of Saurashtra Coast: a preliminary survey. Journal of Marine Science, 1, 10-13.

KRAMARSKY-WINTER, E., AROTSKER, L., RASOULOUNIRIANA, D., SIBONI, N., LOYA, Y. \& KUSHMARO, A. 2014. The possible role of cyanobacterial filaments in coral black band disease pathology. Microbial Ecology, 67(1), 177-185.
KUEHL, K., JONES, R., GIBBS, D. \& RICHARDSON, L. 2011. The roles of temperature and light in black band disease (BBD) progression on corals of the genus Diploria in Bermuda. Journal of Invertebrate Pathology, 106(3), 366-370.

KUTA, K. G. \& RICHARDSON, L. L. 1996. Abundance and distribution of black band disease of corals in the northern Florida Keys. Coral Reefs, 15(4), 219-223.

LAJEUNESSE, T. C. 2001. Investigating the biodiversity, ecology, and phylogeny of endosymbiotic dinoflagellates in the genus Symbiodinium using the ITS region: in search of a "species" level marker. Journal Phycology, 37(5), 866-880.

LAJEUNESSE, T. C. 2002. Diversity and community structure of symbiotic dinoflagellates from Caribbean coral reefs. $\mathrm{Ma}$ rine Biology, 141, 387-400.

MIGOTTO, A. E. 1997. Anthozoan bleaching on the southeastern coast of Brazil in the summer of 1994. In: Proceedings of the 6th International Conference on Coelenterate Biology, 16-21 July, Leeuwenhorst, Noordwijkerhout, Netherlands, 1, 329-335.

MILLER, A. W. \& RICHARDSON, L. L. 2012. Fine structure analysis of black band disease (BBD) infected coral and coral exposed to the BBD toxins microcystin and sulfide. Journal of Invertebrate Pathology, 109, 27-33.

MOREIRA, A. P. B., TONON, L. A. C., PEREIRA, C.V., ALVES JR, N., AMADO-FILHO, G. M., FRANCINI-FILHO, R. B., PARANHOS, R. \& THOMPSON, F.L. 2014. Culturable heterotrophic bacteria associated with healthy and bleached scleractinian Madracis decactis and the Fireworm Hermodice carunculata from the Remote St. Peter and St. Paul Archipelago, Brazil. Current Microbiology, 68, 38-46.

PALMER, C. V., BYTHELL, J. C. \&WILLIS, B. L. 2011 a. A comparative study of phenoloxidase activity in diseased and bleached colonies of the coral Acropora millepora. Developmental and Comparative Immunology, 35(10), 1096-1099.

PALMER, C. V., TRAYLOR-KNOWLES, N. G., WILLIS, B. L. \& BYTHELL, J. C. 2011b. Corals use similar immune cells and wound-healing processes as those of higher organisms. PloS ONE, 6, e23992.

PALMER, C.V., BYTHELL, J.C. \& WILLIS, B.L. 2012. Levels of immunity parameters underpin bleaching and disease susceptibility of reef corals. FASEB Journal, 24, 1-12.

PERÉZ, C. D., VILA-NOVA, D. A. \& SANTOS, A. M. 2005. Associated community with the zoanthid Palythoa caribaeorum (Duchassaing and Michelotti, 1860) (Cnidaria, Anthozoa) from littoral of Pernambuco, Brazil. Hydrobiologia, 548(1), 207-215.

PHILIPP, E. \& FABRICIUS, K. 2003. Photophysiological stress in scleractinian corals in reponse to short-term sedimentation. Journal of Experimental Marine Biology and Ecology, 287(1), 57-78.

PORTER, J. W., TORRES, C., SUTHERLAND, K. P., MEYERS, M. K., CALLAHAN, M. K., RUZICKA, R. \& COLELLA, M. 2011. Prevalence, severity, lethality, and recovery of dark spots syndrome among three Floridian reef-building corals. Journal of Experimental Marine Biology an Ecology, 408(1-2), 79-87.

RABELO, E. F., SOARES, M. O. \& MATTHEWS-CASCON, H. 2013. Competitive Interactions among zoanthids (Cnidaria: Zoanthidae) at intertidal zone of Northeast Brazil. Brazilian Journal of Oceanography, 61(1), 35-42.

RABELO, E. F., ROCHA, L. L., COLARES, G. B., BOMFIM, T. A., NOGUEIRA, V. L. R., KATZENBERGER, M., MATTHEWS-CASCON, H. \& MELO, V. M. M. 2015. Symbiodinium diversity associated with znthids (Cnidaria: Hexacorallia) in Northeastern Brazil. Symbiosis, 64, 105-113. 
RICHARDSON, L. L. 2004. Black band disease. Coral health and disease. Berlin: Springer-Verlag Heidleberg.

RICHARDSON, L. L. 1998. Coral diseases: what is really known? Trends in Ecology and Evolution, 13(11), 438-443.

RODRÍGUEZ-VILLALOBOS, J. C. \& REYES-BONILLA, H. 2019. History of perspectives on the study of coral disease in the eastern tropical Pacific. Diseases of Aquatic Organisns, 136, 243-253.

ROHLFS, C. M. \& BELÉM, M. J. C. 1994. O gênero Zoanthus no Brasil. I. Caracterização e revisão anatômica de Zoanthus sociatus (Cnidária, Zoanthinaria, Zoanthidae). Iheringia Série Zoologia, 77, 135-144.

ROWAN, R., KNOWTON, N., BAKER, A. \& JARÁ, J. 1997. Landscape ecology of algal symbionts creates variation in episodes of coral bleaching. Nature, 388, 265-269.

SALM, R. V., SMITH, S. E. \& LLEWELLYN, G. 2001. Mitigating the impact of coral bleaching through marine protected area design. In: Proceedings of the 9th International Coral Reef Symposium, 23-27 October, Bali, Indonesia, 81-89.

SANTOS, G. S., AMARAL, F. D., SASSI, C. F. C. \& SCHWAMBORN, R. 2016. Response of the zooxanthellae of Palythoa caribaeorum (Cnidaria: Zoanthidae) to different environmental conditions in coastal and oceanic ecosystems of the Tropical Atlantic. Helgoland Marine Research, 70, 2-7.

SANTOS, M. E. A., KITAHARA, M. V., LINDNER, A. \& REIMER, J. D. 2016. Overview of the order Zoantharia (Cnidaria: Anthozoa) in Brazil. Marine Biodiversity, 46(3), 547-559.

SASSI, R., SASSI, C. F. C., GORLACH-LIRA, K. \& FITT, W. K. 2015. Pigmentation changes in Siderastrea spp. during bleaching events in the costal reefs of northeastern Brazil. Latin American Journal of Aquatic Research, 43, 176-185.

SÉRÉ, M., WILKINSON, D. A., SCHLEYER, M. H., CHABANET, P., QUOD, J. P. \& TORTOSA, P. 2016. Characterization of an atypical manifestation of black band disease on Porites lutea in the Western Indian Ocean. Peer Journal of Life and Environmental Sciences, 4, e2073.
SOARES, C. L. S., PÉREZ, C. D., MAIA, M. B. S., SILVA, R. S. S. \& MELO, L. F. A. 2006. Avaliação da atividade antiinflamatória e analgésica do extrato bruto hidroalcoólico do zoantídeo Palythoa caribaeorum (Duchassaing and Michelotti, 1860). Brazilian Journal of Pharmacognosy, 16(4), 463-468.

SOARES, M. O., RABELO, E. F. \& MATHEWS-CASCON, H. 2011. Intertidal Anthozoans from the coast of Ceará (Brazil). Revista Brasileira de Biociência, 9, 437-443.

SOARES, M. O. \& RABELO, E. F. 2014. Primeiro registro de branqueamento de corais no litoral do Ceará (NE, Brasil): indicador das mudanças climáticas? Geociência, 33, 1-10.

SPIER, D. \& GERUM, H. 2017. First record of predation on the Zoanthid Palythoa caribaeorum (Anthozoa, Cnidaria) and the fish Scomberomorus brasiliensis (Scombridae) by the green turtle (Chelonia mydas) in South Brazil. Marine Biodiversity, 47, 777-778.

SUDEK, M., WORK, T. M., AEBY, G. S. \& DAVY, S. K. 2012. Histological observations in the Hawaiian reef coral, Porites compressa, affected by Porites bleaching with tissue loss. Journal of Invertebrate Pathology, 111(2), 121-125.

TOLLER, W. W., ROWAN, R. \& KNOWLTON, N. 2001. Zooxanthellae of the Montastrea annularis species complex: Patterns of distribution of four taxa of Symbiodinium on different reefs and across depths. The Biological Bulletin, 201(3), 348-359.

TRAYLOR-KNOWLES, N., ROSE, N. H. \& PALUMBI, S. R. 2017. The cell specificity of gene expression in the response to heat stress in corals. Journal of Experimental Biology, 220, 18371845.

WILLIAMS, G. J., WORK, T. M., AEBY, G. S., KNAPP, I. S. \& DAVY, S. K. 2011. Gross and microscopic morphology of lesions in Cnidaria from Palmyra Atoll, Central Pacific. Journal of Invertebrate Pathologu, 106(2), 165-173.

WORK, T. M., AEBY, G. S. \& HUGHEN, K. A. 2016. Gross and microscopic lesions in corals from micronesia. Veterinary Pathology, 53(1), 153-16. 